\title{
Facial papules and lung cysts: a case of Birt-Hogg- Dubé syndrome
}

\author{
Paul Griffiths, ${ }^{\oplus}$ Alex Bull
}

Respiratory Medicine, Royal Liverpool and Broadgreen Hospitals NHS Trust, Liverpool, UK

\section{Correspondence to} Dr Paul Griffiths, paul_griffiths@live.com

Accepted 19 August 2019

\section{DESCRIPTION}

A 72-year-old woman with a chronic cough was referred to the respiratory clinic due to the presence of basal lung cysts on CT of the thorax (figure 1A). She was a never smoker, and other than a longstanding dry cough she was clinically well with no other symptoms and no history of pneumothorax. She had also recently been referred to the dermatology clinic due to a slow growing basal cell carcinoma (BCC) on her right chest wall. At the time of review, multiple pale papules were noted on her face (figure 1B). The patient reported that they had been present for around 50 years, with multiple first-degree family members also affected. Subsequent excision confirmed the presence of a BCC on the chest, and punch biopsy found the facial lesions to represent fibrofolliculomas, benign tumours of the hair follicle. The combination of multiple fibrofolliculomas in the presence of lung cysts prompted genetic testing, which demonstrated a mutation in the FLCN gene (heterozygous pathogenic variant c.1285dupC (p.His429Profs $\left.{ }^{\wedge} 27\right)$ ) confirming a diagnosis of Birt-Hogg-Dubé syndrome.

Birt-Hogg-Dubé (BHD) syndrome is an autosomal dominant condition caused by mutation of the FLCN gene which encodes the protein folliculin, a tumour suppressor protein highly expressed within the lungs, skin and kidneys. Consequently, most clinical features are observed in these organs. The characteristic skin lesions are facial papules (fibrofolliculomas and trichodiscomas) and skin tags (acrochordons). ${ }^{1}$ Fibrofolliculomas appear as white or skin-coloured papules on the upper body in patients over 20 years of age and can appear identical to trichodiscomas. Although common, approximately $25 \%$ of FLCN mutation carriers over 20 years of age do not manifest characteristic skin lesions, highlighting the phenotypic heterogeneity of the condition. ${ }^{2}$

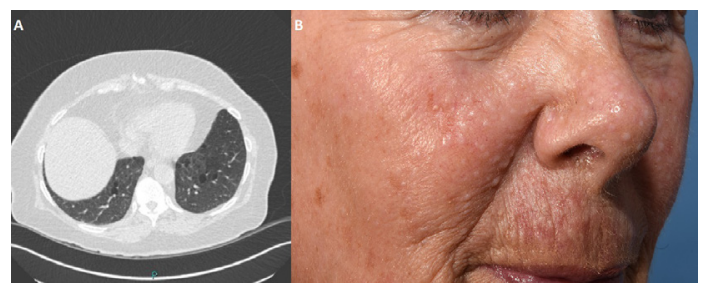

Figure 1 (A) Axial CT slice through the lung bases demonstrating multiple cystic changes within the lung parenchyma. (B) Photograph of the face demonstrating multiple pale papules on the cheeks and nose, consistent with fibrofolliculomas.

\section{Learning points}

- Birt-Hogg-Dubé (BHD) syndrome should be considered in the differential diagnosis of a patient presenting with lung cysts, when the presence of the classic skin findings may help to make the diagnosis.

- Annual screening for renal tumours should be offered to patients with BHD syndrome due to an increased lifetime risk of developing renal cancers compared with the general population.

- Given the autosomal dominant pattern of inheritance, first-degree family members should be offered genetic testing.

Pulmonary changes are an early finding with approximately $90 \%$ of patients having lung cysts on imaging. There is a family history of pneumothorax in around $35 \%$ of cases, with individuals having a 50 -fold increased lifetime risk of pneumothorax. ${ }^{34}$ Interestingly, around 5\%-10\% of apparent primary spontaneous pneumothoraces have been attributed to underlying BHD syndrome, likely reflecting underdiagnosis of this condition. ${ }^{5}$

Many benign and malignant tumours have been described in BHD syndrome, including BCC; however, renal tumours are the only type to be accepted as part of the BHD phenotype. ${ }^{67}$ There is a sevenfold increased risk of developing renal tumours which can be benign or malignant, ranging from oncocytomas to chromophobe renal cell carcinomas, may be multifocal and bilateral and often present earlier than the general population at an average age of 50 years. ${ }^{8}$ Although there are no standard guidelines, annual surveillance of the kidneys is recommended. In this case, CT of the kidneys demonstrated no evidence of renal neoplasia, and annual surveillance with renal ultrasound is planned. We postulate that, given the late age at diagnosis and lack of prior complications, this patient may well have 'outlived' much of the risk associated with BHD syndrome. Nonetheless, the diagnosis also has implications for family members, given the autosomal dominant pattern of inheritance. The patient was counselled, and all first-degree relatives were offered genetic testing.

In conclusion, this patient presented relatively late in life having had a history of skin lesions for 50 years. There was no prior associated morbidity related to BHD syndrome, such as pneumothorax or renal tumours, and no family history of the same. The BCC may be related to the underlying genetic abnormality; however, the causal link is not established-it is fortuitous that the presence of a BCC led to the other cutaneous features being 
diagnosed. The original presenting symptom - cough - was deemed secondary to laryngopharyngeal reflux, with treatment achieving good symptomatic response. It is unlikely that small focal lung cysts would contribute to her symptomatology.

Contributors $P G$ and $A B$ conceived the idea for the manuscript, both contributing to the writing and revisions of the text. Both authors have reviewed and approve the final version.

Funding The authors have not declared a specific grant for this research from any funding agency in the public, commercial or not-for-profit sectors.

Competing interests None declared.

Patient consent for publication Obtained.

Provenance and peer review Not commissioned; externally peer reviewed.

\section{REFERENCES}

1 Birt AR, Hogg GR, Dubé WJ. Hereditary multiple fibrofolliculomas with trichodiscomas and acrochordons. Arch Dermatol 1977:113:1674-7.
2 Schmidt LS, Nickerson ML, Warren MB, et al. Germline BHD-mutation spectrum and phenotype analysis of a large cohort of families with Birt-Hogg-Dubé syndrome. Am J Hum Genet 2005;76:1023-33.

3 Zbar B, Alvord WG, Glenn G, et al. Risk of renal and colonic neoplasms and spontaneous pneumothorax in the Birt-Hogg-Dubé syndrome. Cancer Epidemiol Biomarkers Prev 2002:11:393-400.

4 Toro JR, Wei M-H, Glenn GM, et al. BHD mutations, clinical and molecular genetic investigations of Birt-Hogg-Dube syndrome: a new series of 50 families and a review of published reports. J Med Genet 2008;45:321-31.

5 Johannesma PC, Reinhard R, Kon Y, et al. Prevalence of Birt-Hogg-Dubé syndrome in patients with apparently primary spontaneous pneumothorax. Eur Respir J 2015;45:1191-4.

6 Tong Y, Schneider JA, Coda AB, et al. Birt-Hogg-Dubé syndrome: a review of dermatological manifestations and other symptoms. Am I Clin Dermatol 2018:19:87-101.

7 Leter EM, Koopmans AK, Gille JJ, et al. Birt-Hogg-Dubé syndrome: clinical and genetic studies of 20 families. J Invest Dermatol 2008;128:45-9.

8 Pavlovich CP, Walther MM, Eyler RA, et al. Renal tumors in the Birt-Hogg-Dubé syndrome. Am J Surg Pathol 2002;26:1542-52.

Copyright 2019 BMJ Publishing Group. All rights reserved. For permission to reuse any of this content visit

https://www.bmj.com/company/products-services/rights-and-licensing/permissions/

BMJ Case Report Fellows may re-use this article for personal use and teaching without any further permission.

Become a Fellow of BMJ Case Reports today and you can:

- Submit as many cases as you like

- Enjoy fast sympathetic peer review and rapid publication of accepted articles

- Access all the published articles

Re-use any of the published material for personal use and teaching without further permission

Customer Service

If you have any further queries about your subscription, please contact our customer services team on +44 (0) 2071111105 or via email at support@bmj.com.

Visit casereports.bmj.com for more articles like this and to become a Fellow 